\title{
Strategic Profit Planning and Organizational Performance in Public Sector Commercial Banks of Nepal
}

\author{
Dr. Dilip Parajuli \\ Associate Professor, Bhaktapur Multiple Campus, Tribhuvan University, Nepal \\ Dr. Prakash Shrestha* \\ Lecturer, Nepal Commerce Campus, Tribhuvan University, Nepal
}

\begin{abstract}
This study aimed to examine strategic profit planning and its effect on the organizational performance of the public sector commercial banks of Nepal. Using a standardized questionnaire, primary data was obtained. Based on a judgment sampling method, 450 employees were taken for the sample. 72.70 percent of senior and middle-level employees participated in this study. In this study, budget planning, budget participation, budgetary sophistication, and budgetary control were considered as the independent variables and organizational performance was a dependent variable. The findings showed that the dimensions of strategic profit planning had a positive and important impact on the organizational performance of public commercial banks in terms of budget planning and budget participation. However, the other two dimensions of strategic profit planning like budgetary sophistication and budgetary control had a negative impact on the organizational performance of these banks. In such realities, companies need to focus on other factors that contribute to better performance apart from strategic profit planning dimensions, like employee motivation and invest more in staff development to enhance their organizational performance.
\end{abstract}

Keywords: Budgeting, Commercial banks, Organizational performance, Public sector, Strategic profit planning DOI: $10.7176 / \mathrm{RJFA} / 11-22-01$

Publication date: November $30^{\text {th }} 2020$

\section{Introduction}

One of the most critical methods used to organize and manage company activities is profit planning. It is an aspect of an organization's overall planning process (Welsch, Hilton \& Gordon, 2000). Budget or profit plans are financial plans established as a guide to the future operation's power. Profit planning is an income calculation and predetermination, expenditures that predict how much revenue will be generated, and how it should be spent to meet the criteria for investment and profit (Bhandari, 2017). The approach of using systematic criteria and thorough investigation to devise, execute, and monitor strategy and formally record organizational goals is strategic profit planning (George, Walker \& Monster, 2019). It consists of a series of underlying processes designed to build or exploit a situation to produce a business with a more desirable outcome. This is somewhat different from the more defensive conventional tactical benefit planning focused on the movement of competition to guide the company's move. Strategic profit planning offers general guidance for individual units of industry, such as financial priorities, programs, human resources, and marketing (Hall, Jones, \& Raffo, 2007).

This research believes that there is an impact of strategic profit planning on organizational performance. Organizational performance is a company's ability to obtain and maximize its scarce resources and valuables as possible in the quest of its operational goals, whilst strategic planning is a progressive tool that managers should be engaged in (Kaufman et al., 2003). If strategic profit planning is accessible and well-executed, organizations will have minor or no challenges in handling external changes. For organizations to survive, they ought to operate successfully with forces present in the environment that are unstable and uncontrollable which can have a great effect on the decision-making process (Owolabi, 2012). Based on these discussions, this study aims to analyze the impact of strategic profit planning on organizational performance regarding the public commercial banks of Nepal.

\section{Literature Review}

\subsection{Strategic Profit Planning}

Strategic profit planning is a predetermined detailed plan of action developed and distributed as a guide to current operations and as a partial basis for the subsequent is a tool that may be used by the management in planning the future course of actions and controlling the actual performance (Gupta, 1992). Such planning is commonly practiced to enhance the organization's performance. It is the cornerstone of every organization without which the organization will never know where it is going or when to achieve its objectives (Nyanaro \& Bett, 2018). The strategic profit planning is broad and it usually encompasses five or more years in the future. The development of strategic profit planning a process that involves managerial decisions and ideally a high level of management participation (Welsch et al., 2000). In this study budget planning, budget participation, budgetary sophistication, and budgetary control are considered as the key aspects of strategic profit planning. 


\section{Budget Planning}

It involves defining revenue streams and taking into account both current and potential expenditures, trying to achieve the financial goals of an entity. A budget planner's primary goal is to ensure savings after spending allocation. The budget is an important microeconomic concept that can be interpreted in monetary terms as an organizational strategy. Some variants of this term are the business start-up budget, corporate budget, event management budget, government budget, and personal or family budget (George et al., 2019).

\section{Budget Participation}

It is a budgeting system in which the budget formation process deliberately includes all individuals affected by a budget. This approach to bottom-up budgeting aims to achieve more realistic budgets, with much less input from staff, than top-down budgets enforced by senior management on a business (Abata, 2014). Budget participation is often better for morale and helps to lead to more attempts from workers to accomplish what they anticipated in the budget. However, high-level strategic issues are not taken into account by a solely participatory budget, so management needs to provide workers with feedback on the overall direction of the organization and how their divisions fit into that direction (Kohzadi \& Hafezi, 2016).

\section{Budgetary Sophistication}

The application of sophisticated budgeting practices is complicated and conceptually difficult to understand. Adopting sophisticated budgeting practices is thus not without costs: both time and effort must be expended to be able to use them. In determining the appropriate level of sophisticated budgeting practices, organizations will compare the net benefits of budgeting methods and tools to their costs. Generally, it is hypothesized that options become more valuable as uncertainty increases. The theory thus suggests that sophisticated budgeting practices are most valuable in case of high uncertainty, in the situation; the costs of sophisticated budgeting practices are likely offset by additional gains from successful investment projects (King \& Adetayo, 2018).

\section{Budgetary Control}

It refers to how often managers in a given accounting cycle use budgets to monitor and control expenses and activities. In other words, budgetary control is a mechanism for managers to set budgets for financial and performance targets, compare the actual results, and change performance as required (Kohzadi \& Hafezi, 2016). Budgetary control is a method for managers to set financial and performance goals.

\subsection{Organizational Performance}

Organizational performance is another key construct of this study. It is the actual output of an organization measured against the expected outputs. It is a summary of three key identifiable, measurable, and specific outcome areas such as financial performance, shareholder return, and product performance (Richard et al. 2009). Financial performance is measurable in profits, return on investments, and return on assets (Parajuli \& Shrestha, 2020a, 2020b). Shareholder return is measurable in total shareholder return, as well as a measure of economic value addition. Product performance, on the other hand, can be measured in sales or market share achieved, new market penetration, and customer feedback evaluation (Nzuki, 2017). However, in this study organizational performance is measured in terms of return on assets, return on equity, market share growth, total cost reduction, sale growth, and financial liquidity.

\subsection{Strategic Profit Planning and Level of Organizational Performance}

Strategic planning results in superior financial efficiency, calculated in terms of financial metrics commonly agreed (e.g. revenue, net profit, ROI, ROE, ROS), it is argued. Nevertheless, more recent research (Miller and Cardinal, 2011; Schwenk and Shrader, 2014) offer compelling proof that superior financial output does indeed benefit from strategic planning. Thus, most studies have explored the relationship between strategic profit planning and performance (Gup \& Whitehead, 1989; Hopkins \& Hopkins, 1994) and have concluded that businesses with a structured strategic profit planning process outperform those that do not.

Besides, companies that take a constructive strategic approach have stronger performance than those that take a reactive strategic approach. This evidence indicates the importance of having a systematic, constructive strategic planning mechanism in an organization, whether large or small and the need to infect it.

Kohzadi \& Hafezi (2016) found that most companies have clear strategies and that there has been no substantial association between the strength of strategic planning and the number of employees. King \& Adetayo (2018) reported that top management should be more involved in the strategic profit planning phase to achieve defined organizational goals, which in turn would promote organizational growth and development. George et al. (2019) have found that when success is measured as productivity and when strategic profit planning is measured as structured strategic planning, the positive effect of strategic profit planning on organizational performance is greatest. 


\section{Research Methodology}

\subsection{Sample}

There are 27 commercial banks are in operation in Nepal. Out of these, there are three public sector banks namely Agriculture Development Bank Limited (ADBL), Nepal Bank Limited (NBL), and Rastriya Banijya Bank Limited (RBBL).

Total senior and middle-level employees of these banks are considered for the study purposes. Based on a judgment sampling method, 450 employees are taken for the sample. Only 327 (72.70 percent) senior and middlelevel employees participated in this study.

\subsection{Source of Data}

Using a standardized questionnaire, primary data was obtained. The questionnaire contains a 5-points Likert scale, ranging from one (strongly disagree) to five (strongly agree).

\subsection{Research Framework}

In this study, budget planning, budget participation, budgetary sophistication, and budgetary control are considered as the independent variables and organizational performance is a dependent variable. Thus, based on George et al. (2019) Kohzadi and Hafezi (2016), and King and Adetayo (2018) research the model can be adapted and developed as follow:

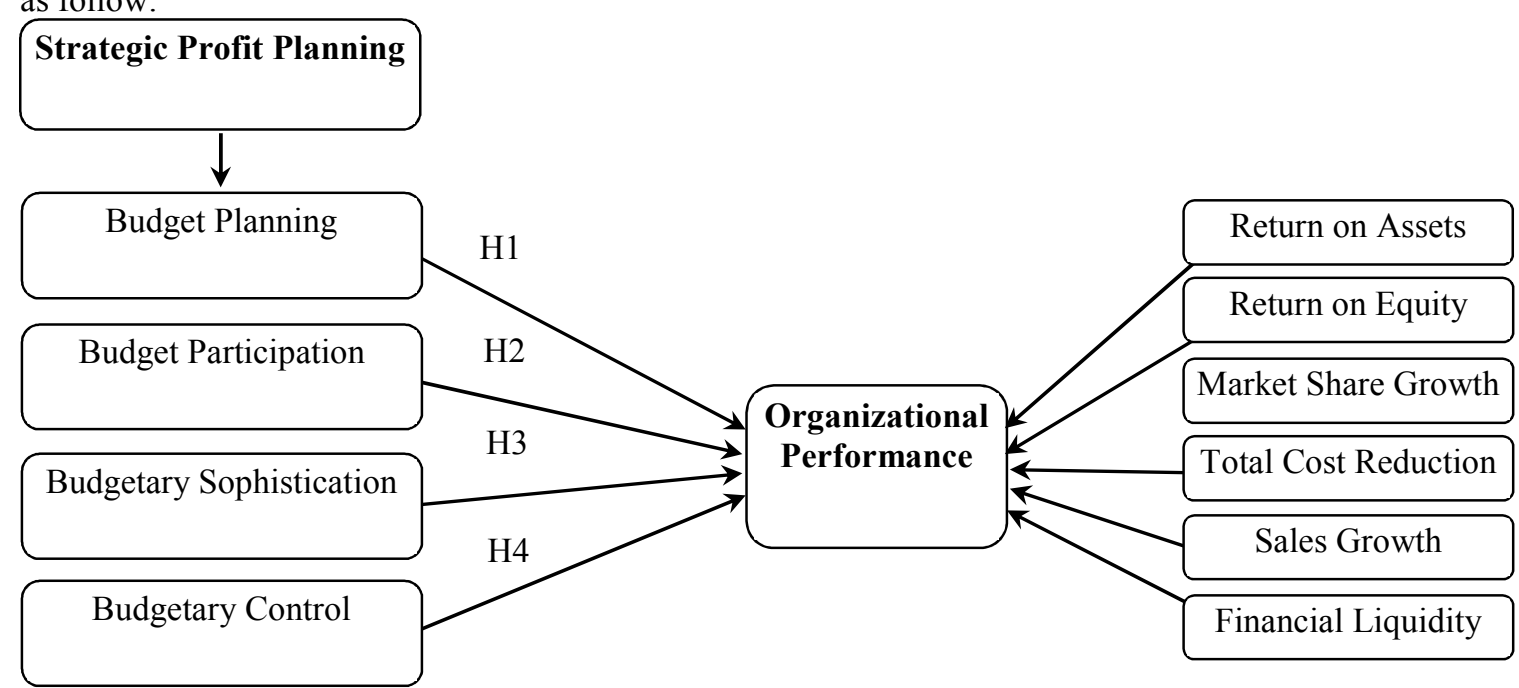

Figure 1. Strategic Profit Planning and Organizational Performance

The following hypotheses were built based on this research framework to investigate the effect of strategic profit planning on organizational performance:

H1: $\quad$ Budget planning has a substantial influence on organizational performance.

H2: $\quad$ Budget participation has a direct effect on organizational performance.

H3: $\quad$ There is a significant impact on organizational performance from budgetary sophistication.

H4: There is a significant impact on organizational performance from budgetary control.

\subsection{Data Analysis Tools}

As methods for data analysis, descriptive statistics such as mean and standard deviation (S.D.), and inferential statistics such as correlation analysis and multiple regression analysis are used.

\subsection{Reliability Test}

Cronbach's Alpha $(\alpha)$ was used to test the reliability of the study. This alpha is also known as the coefficient of reliability (or consistency) so, a coefficient of 0.70 or higher is considered to be acceptable. The reliability test is presented in the following table:

Table 1: Reliability Statistics

\begin{tabular}{lcc}
\hline \multicolumn{1}{c}{ Strategic Profit Planning } & Cronbach's Alpha & Number of Items \\
\hline Budget Planning & 0.84 & 7 \\
Budget Participation & 0.83 & 5 \\
Budgetary Sophistication & 0.72 & 4 \\
Budgetary Control & 0.73 & 4 \\
Organizational Performance & 0.77 & 6 \\
\hline
\end{tabular}


Nunally (1978) reported that the value of Cronbach's Alpha of at least 0.70 is considered as a good indication of constant reliability. Table 1 highlights the value of Cronbach's Alpha for each variable under the study is greater than 0.70 , which support the notion that the study is reliable.

\section{Data Analysis and Results}

4.1 Descriptive Statistics

Table (2) shows the means and standard deviation for each variable used in the study.

Table 2: Descriptive Statistics of Study Variables

\begin{tabular}{lcc}
\hline Variables & Mean & S.D. \\
\hline Budget Planning (BP) & 4.57 & 0.53 \\
Budget Participation (BPP) & 4.14 & 0.68 \\
Budgetary Sophistication (BS) & 4.31 & 0.53 \\
Budgetary Control (BC) & 4.14 & 0.68 \\
Organizational Performance (OP) & 4.37 & 0.47 \\
\hline Source: Field Survey (2020)
\end{tabular}

Source: Field Survey (2020)

Table (2) depicts a summary of all the variables of the study through descriptive statistics analysis. The magnitude of organizational performance of employees is 4.37 with an S.D. of 0.47 , which means organizational performance is high within the public sector commercial banks. Among the factor of strategic profit planning, budget planning has the highest mean of 4.57 with an S.D. of 0.53 whereas budget participation and budgetary control have the least mean of 4.14 with an S.D. of 0.68 .

\subsection{Relationship between Strategic Profit Planning with Organizational Performance}

A Pearson correlation was run to establish how the variables were related to each other. Table (3) shows the correlation results of the study on the variables.

Table 3: Correlation Results

\begin{tabular}{lc}
\hline Strategic Profit Planning Dimensions & Organizational Performance \\
\hline Budget Planning & $0.92^{* *}$ \\
Budget Participation & $0.81^{* *}$ \\
Budgetary Sophistication & $0.91^{* *}$ \\
Budgetary Control & $0.85^{\text {** }}$ \\
\hline
\end{tabular}

$$
\text { Note: } * * p<0.01 .{ }^{*} p<0.05
$$

The results indicate that budget planning, budget participation, budgetary sophistication, and budgetary control are positively related to organizational performance at $0.92,0.81,0.91$, and 0.85 at a 1 percent level of significance. This indicated that no one of the strategic profit planning dimensions had a negative correlation with the performance of the bank. Thus, strategic profit planning had positive associations with organizational performance.

\subsection{Impact of Strategic Profit Planning with Organizational Performance}

This section presents the regression results to examine the impact of strategic profit planning dimensions on organizational performance.

The regression model indicates that there is a positive impact of budget planning and budget participation on organizational performance as indicates by the beta coefficients of 1.086 and 0.524 respectively. However, budgetary sophistication and budgetary control have a negative impact on organizational performance with the beta coefficients of -0.084 and -0.6 .3 respectively.

The results imply that budget planning and budget participation are significant predictors of organizational performance. Thus, these findings provide support for $\mathrm{H} 1$ and $\mathrm{H} 2$. However, budgetary sophistication and budgetary control are not the predictors of organizational performance. Hence, these findings do not support for $\mathrm{H} 3$ and $\mathrm{H} 4$. 
Table 4: Regression Results

\begin{tabular}{|c|c|c|c|c|c|}
\hline \multirow{2}{*}{ Model 1} & \multicolumn{2}{|c|}{ Unstandardized Coefficients } & \multirow{2}{*}{$\begin{array}{c}\begin{array}{c}\text { Standardized } \\
\text { Coefficients }\end{array} \\
\text { Beta } \\
\end{array}$} & \multirow[t]{2}{*}{$\mathbf{t}$} & \multirow{2}{*}{ Sig. } \\
\hline & $\mathbf{B}$ & Std. Error & & & \\
\hline (Constant) & 0.589 & 0.096 & & 6.122 & $0.00 * *$ \\
\hline Budget Planning & 1.072 & 0.109 & 1.086 & 9.85 & $0.00 * *$ \\
\hline Budget Participation & 0.421 & 0.102 & 0.524 & 4.124 & $0.00 * *$ \\
\hline Budgetary Sophistication & -0.091 & 0.077 & -0.084 & -1.171 & 0.243 \\
\hline Budgetary Control & -0.554 & 0.110 & -0.603 & -5.025 & $0.00 * *$ \\
\hline
\end{tabular}

Dependent Variable: Organizational Performance

$R=0.937 ; R^{2}=0.878 ; F=617.967 ; p$-value $=0.000$

$*^{* *}<<0.01 . * p<0.05$

Table 5: Summary of Hypotheses Results

\begin{tabular}{llc}
\hline & \multicolumn{1}{c}{ Hypotheses } & Decision \\
\hline H1: & Budget planning has a substantial influence on organizational performance. & Accepted \\
\hline H2: & Budget participation has a direct effect on organizational performance. & Accepted \\
\hline H3: & $\begin{array}{l}\text { There is a significant impact on organizational performance from budgetary } \\
\text { sophistication. }\end{array}$ & Rejected \\
\hline H4: & There is a significant impact on organizational performance from budgetary control. & Rejected \\
\hline
\end{tabular}

\section{Discussion and Conclusion}

This study aimed to examine strategic profit planning and its effect on the organizational performance of Nepal's commercial banks in the public sector. Strategic profit planning includes budget planning, budget participation, budgetary sophistication, and budgetary control whereas organizational performance includes return on assets, return on equity, market share growth, total cost reduction, sale growth, and financial liquidity. The study indicated that no one of the strategic profit planning dimensions had a negative correlation with the performance of the banks. Thus, strategic profit planning had a positive and significant relationship with organizational performance.

The findings further showed that the dimensions of strategic profit planning had a positive and important impact on the organizational performance of public commercial banks in terms of budget planning and budget participation. In their studies, Drury (2000), Garrison, Noreen, and Seal (2003) and Joshi, Al-Mudhaki, and Bremser (2003) reported that multiple functions regarding budgeting actions can be accomplished through budgeting in the process of financial decision-making and internal activity of an organization, which ultimately supports the improvement of organizational performance.

in the same way, several scholars have argued that budgetary engagement and organizational performance are closely related (e.g., Shields \& Shields, 1998; Birnberg \& Shields, 1989; Gul et al., 1995; Magner, Welker, \& Campbell, 1995; Tsui, 2001; Qi, 2010). They stated that, through budget participation (the downward information sharing), subordinates gain information from superiors that helps clarify their organizational roles, including their duties, responsibilities, and expected performance, which in turn enhances organizational performance. However, the other two dimensions of strategic profit planning like budgetary sophistication and budgetary control had a negative impact on the organizational performance of these banks. In such realities, companies need to focus on other factors that contribute to better performance apart from strategic profit planning dimensions, like employee motivation and invest more in staff development to enhance their organizational performance.

\section{References}

Abata, M.A. (2014). Participative budgeting and managerial performance in the Nigerian food products sector. Global Journal of Contemporary Research in Accounting, Auditing and Business Ethics, 1(3), 148-167.

Bhandari, B. P. (2017). Profit planning and control in Agricultural Development Bank Limited. Tribhuvan University, Kathmandu.

Birnberg, J.G., \& Shields, J.F. (1989). Three decades of behavioral research: A search for order. Behavioral Research in Accounting, 1, 23-74.

Drury, C. (2000). Management and cost accounting, London: International Thomson Business Press, 4th Edition. Garrison, R.H., Noreen, E.W., \& Seal, W. (2003). Management accounting, New York: McGraw-Hill Education, European Edition.

George, B., Walker, R. M. \& Monster, J. (2019). Strategic Profit Planning and its Improve Organizational Performance. Public Administration Review, 79(6), 810-819.

Gul, F.A., Tusi, Judy S.L., Fong, Steve C.C., \& Kwok, Helen Y.L. (1995). Decentralization as a moderating factor in the budgetary participation performance relationship: Some Hong Kong evidence. Accounting and 
Business Research, 25(98), 107-113.

Gup, B. E. \& Whitehead, D. D. (1989). Strategic planning in banks does it pay. Long Range Planning, 22(1), 124130.

Gupta, S. P. (1992). Management accounting budgeting, business budget and budgetary control. New Delhi: Agra Sahitya Bhawan.

Hall, D., Jones, R., \& Raffo, C. (2007). Business studies. New Delhi: Dorling Kindersley (India) Pvt. Ltd.

Hopkins, W. E. \& Hopkins, S. A. (1994). Want to succeed get with the plan. Journal of Retail Banking, 16(4), 2631.

Joshi, P.L., Al-Mudhaki, J., \& Bremser, W.G. (2003). Corporate budget planning, control and performance evaluation in Bahrain. Managerial Auditing Journal, 18(9), 737-750.

Kaufman, R., Oakley-Browne, H., Watkins, R., \& Leigh, D. (2003). Strategic planning for success: Aligning people, performance, and payoffs. San Francisco, CA: John Wiley \& Sons, Inc.

King, A. \& Adetayo, S. (2018). Impact of strategic profit planning on organizational performance. International Journal of Scientific \& Engineering Research, 9(2), 1256-1262.

Kohzadi, M. \& Hafezi, S. (2016). The effect of strategic planning on organizational performance in industrial estate companies of Gachsaran 2014-2015 years. International Journal of Humanities and Cultural Studies, 1(1), 1098-1108.

Magner, N., Welker, R.B., \& Campbell, T.L. (1995). The Interactive Effect of Budgetary Participation and Budget Favorability on Attitudes toward Budgetary Decision Makers: A Research Note. Accounting, Organizations \& Society, 20(7/8), 611-618.

Miller, C.C. \& Cardinal, L. B. (2011). Strategic planning and firm performance a synthesis of more than two decades of research. Academy of Management Journal, 3(6), 1649-1665.

Nunnally, J.C. (1978), Psychometric Theory, New York, NY: McGraw-Hill.

Nyanaro, N. N. \& Bett, S. (2018). Influence of strategic planning on performance of commercial banks in Kenya: Case of Barclays Bank of Kenya. International Academic Journal of Human Resource and Business Administration, 3(2), 235-255.

Nzuki, B.M. (2017). Strategic planning practices and organizational performance of Sandoz Gmbh Kenya. School of Business, University of Nairobi, Nairobi.

Owolabi, S. (2012). The effects of strategic profit planning on corporate performance in university education. Kuwait Chapter of Arabian Journal of Business \& Management Review, 2(4), 116-119.

Parajuli, D., \& Shrestha, P. (2020a). The relationship between balanced scorecard evaluation approach and organizational performance of commercial banks of Nepal. Research Journal of Finance and Accounting, 11(18), 1-8.

Parajuli, D., \& Shrestha, P. (2020b). Impact of balance scorecard dimensions on bank performance: Evidence from Nepal. Research Journal of Finance and Accounting, 11(20), 7-15.

Qi, Y. (2010). The impact of the budgeting process on performance in small and medium-sized firms in China. University of Twente, Netherlands.

Richard, P.J., Devinney, T.M., Yip, G.S, \& Johnson, G. (2009). Measuring organizational performance: Toward methodological best practice. Journal of Management, 35(3), 718-804.

Schwenk, C. R. \& Shrader, C. B. (2014). Effects of formal strategic profit planning on financial performance in small firms. Entrepreneurship Theory and Practice,17(3), 53-64.

Shields, J.F., \& Shields, M.D. (1998). Antecedents of participative budgeting. Accounting, Organization \& Society, 23(1), 49-76.

Tsui, J.L. (2001). The impact of culture on the relationship between budgetary participation, management accounting systems, and managerial performance: An analysis of Chinese and western managers. The International Journal of Accounting, 36(2), 125-146.

Welsch, G. A., Hilton, R. W., \& Grodon, P. N. (2000). Budgeting profit planning control. New Delhi: PrenticeHall of India. 